\title{
Chromium, nickel and zinc induced histopathological alterations in the gill of Indian common carp Labeo rohita (Ham.)
}

\author{
N.V. Bhatkar \\ Department of Zoology, Shri Shivaji College, Akot- 444101(MS), INDIA \\ E-mail:bhatkarneha@ hotmail.com
}

Abstract: Degenerative histopathalogical alterations were seen in gills due to chronic exposure of the fish, Labeo rohita to chlorides of chromium, nickel and zinc for 30 days. However, more severe degenerative changes were observed in case of zinc chloride exposed fish than nickel chloride and chromium chloride treated fishes, indicating more toxic nature of zinc chloride. Mucus secretion over the gill lamellae was seen prominently in all the experimental fishes. However, in zinc chloride treated fish there was excessive mucus secretion after ten days of exposure and after thirty days, epithelial lifting was seen. In chromium chloride and nickel chloride treated fishes there was basal hyperplasia, which indicated compensatory mechanism in ion regulation to adjust with the toxic stress.

Keywords: Chromium, Nickel, Zinc, Labeo rohita, Gill

\section{INTRODUCTION}

Due to the rapid industrial development during last few decades in India, the disposal of industrial effluents has become a serious problem. A huge amount of wastewater generated from factories is discharged on land or into the running water. Wastewater is characterized by low $\mathrm{pH}$, high BOD and COD values and contains a high percentage of organic and inorganic materials (Chauhan, 1991). Heavy metal contamination has been reported in aquatic organisms (Adham et al., 2002 and Olojo et al., 2005). These pollutants build up in the food chain and are responsible for adverse effects and death in the aquatic organisms (Farkas et al., 2002). Fish are widely used to evaluate the health of aquatic ecosystems and physiological changes serve as biomarkers of environmental pollution (Kock et al., 1996).

Good quality of food for consumption can only be produced in an environment free from contamination. Fish, having great economic importance, are affected immensely by various chemicals including heavy metals directly or indirectly in various ways. Several reports indicate high mortality of juvenile fish and reduced breeding potentiality of adults after long term exposure to heavy metals (Olojo et al., 2005). The freshwater fish, Labeo rohita is of great commercial importance because it is the most common fish widely consumed worldwide. Therefore, it can be a good model to study the responses to heavy metal contaminations.

Chromium plating is one of the major uses of chromium. Effluents from these processes are strongly acidic and may contain the toxic hexavalent chromium or the less toxic trivalent form. Steel fabrication, paint, pigment manufacturing and leather tanning constitute other major uses of chromium.

Nickel finds numerous applications in many industries because of its corrosion resistance high strength and durability, pleasing appearance, good thermal and electrical conductivity and alloying ability. The production of alloys accounts for approximately $75 \%$ of total nickel consumption (Wilson et al., 1986, Nriagu and Pacyna, 1988, Nicolaidou and Nott, 1989).

Zinc, an essential trace metal becomes toxic when the nutritional supply becomes excessive. Moderately increased zinc concentrations in water stemming from the release of zinc from drainage pipes due to corrosion. The main uses of zinc are in the manufacture of galvanized iron, bronze, paint (white), rubber, glazes, enamel glass, paper, as a wood preservative ( $\mathrm{ZnCl}_{2}$, fungicidal action), petrochemicals, and fertilizers and in steam generation power plants etc. (Nriagu and Pacyna, 1988).

Gills are the first target of waterborne pollutants due to the constant contact with the external environment, as well as the main place for heavy metal uptake (Campbell et al., 1979; and Perry and Laurent 1993). It is well known that changes in fish gill are among the most commonly recognized responses to environmental pollutants (Mallatt, 1985; Laurent and Perry, 1991; Au, 2004 and Antonio et al., 2007). The organisms develop a protective defense against the deleterious effects of heavy metals and other xenobiotics that produce degenerative changes like oxidative stress in the body (Filipovic and Raspor, 2003; Abou EL-Naga et al., 2005, Vinodhini and Narayanan, 2008). A histological study is necessary to 
monitor the recovery because survival / mortality criteria do not alone provide an accurate assessment of the circumstances of stress condition. The investigation of histological changes in gill of fish is one of the accurate ways to assess the effects of xenobiotics compounds in experimental studies. With this in view, an attempt has been made to observe the chronic effect of sublethal concentration of chromium chloride, nickel chloride and zinc chloride on gill of the fish, Labeo rohita. This investigation presents a reliable indicator of the aquatic ecosystem contamination and the possible negative impact of the surrounding environment.

\section{MATERIALS AND METHODS}

Disease-free fish, Labeo rohita were bathed in $1 \%$ $\mathrm{KMnO}_{4}$ solution and acclimated in big glass aquarium of 400 to 450 liter capacity for a period of 15 days. Chlorine free aged tap water was used in the aquaria. The water had pH $8.2 \pm 0.2$; hardness $280 \mathrm{mg} / \mathrm{l}$; D.O. $6.2 \mathrm{mg} / \mathrm{l}$; total alkalinity $310 \mathrm{mg} / \mathrm{l}$ and temperature $25 \pm 2^{\circ} \mathrm{C}$. The fish were fed with rice bran daily at $10.30 \mathrm{am}$. The water in the aquaria was changed daily after the consumption of food supplied. The healthy fish of both the sexes and uniform size and weight $(125 \pm 2 \mathrm{~g})$ were selected from the lot for experimental purpose. Initially $96 \mathrm{~h} \mathrm{LC}_{50}$ doses were determined for chromium, nickel and zinc heavy metal compounds by the method as described in standard methods by APHA (1998).

Forty healthy fish from the stock were selected and were divided into four groups. Group-I: Consisted of 10 fish in aged tap water which served as control. Group-II: Consisted of 10 fish kept in toxicant water containing $6 \mathrm{mg} / \mathrm{l}$ chromium chloride for 30 days. Group-III: Consisted of 10 fish kept in toxicant water containing $4 \mathrm{mg} / \mathrm{l}$ nickel chloride for 30 days. Group-IV: Consisted of 10 fish kept in toxicant water containing $2 \mathrm{mg} / \mathrm{l}$ zinc chloride for 30 days. The fish were exposed to $6 \mathrm{mg} / \mathrm{l}$ of chromium chloride, $4 \mathrm{mg} / \mathrm{l}$ of nickel chloride and $2 \mathrm{mg} / \mathrm{l}$ of zinc chloride, separately, which are $1 \backslash 10^{\text {th }}$ of their $96 \mathrm{~h} \mathrm{LC}_{50}$ concentrations. To avoid the effects of starvation, the fish were fed on the rice bran at the average feeding rate of $25 \mathrm{mg}$ food $\backslash \mathrm{gm}$ fish $\backslash$ day. The toxicant solutions and the aged tap water (control) were renewed every day in the morning after removing the unused food, to maintain uniform test concentrations throughout the experimental period. The controls as well as the experimental fish were sacrificed on the day 10 and 30. The gill arch at the right side of the each fish was dissected out and rinsed in fresh water fish saline to remove the bloodstains.

Then the gills were cut into small pieces of desirable size and fixed immediately into aqueous Bouin's fluid. The tissues were further processed by standard methods as described by Weissman (1972). The sections were cut and stained with haematoxylin-eosin, processed further, cleaned and then observed under microscope.

\section{RESULTS}

Healthy and control gill is characterized by the presence of intact primary lamellae along with the secondary lamellae. The secondary lamellae show mucous cells lying scattered on both the sides of epithelium. The pilaster cells are scattered and the basement membrane traverses through the secondary gill lamella (Fig. 1).The gills of chromium chloride exposed fishes after ten days showed visible shrinkage in the primary and secondary lamellae with a loss of respiratory epithelial cells (Fig2). The secondary gill lamellae were bent irregularly and the epithelium at the tip was thickened to form a clubbed structure. Necrosis of few epithelial cells and damaged RBCs were evident after 30 days treatment with a visible space between primary and secondary lamellae and a moderate basal hyperplasia of secondary lamellae (Fig.3) was seen. Fusion of some secondary lamellae was also evident.

After ten days of exposure to nickel chloride $(4 \mathrm{mg} / \mathrm{l})$ irregular disruption of epithelial cells along with mucus was prominently seen (Fig. 4). But after thirty days of exposure to same toxicant, fusion of secondary lamellae, their shortening with basal hyperplasia was seen (Fig. 5).A very distinct effect was seen in the gills of fish exposed to zinc chloride for ten days and that is excessive secretion of mucus which almost filled the gaps between adjacent secondary lamellae (Fig. 6).After 30 days of exposure to zinc chloride, epithelial layer was lifted up from the basement membrane of the gill arch, filaments and the lamellae (Fig.7).

\section{DISCUSSION}

The gills being delicate structures get affected easily if the surrounding media is contaminated (Roy and Dutta Munshi, 1991 and Olojo et al., 2005). One of the interesting observations in the present study is that mucous secreting cells of the gill epithelium were found in active stage. Increased mucous production which has some detoxification properties (Bender and Westman, 1979) may be to avoid direct contact to toxicants to the gill epithelium, while respiratory cells showed hypertrophy followed by atrophy, as also reported by Chauhan and Pandey (1987) and Antonio et al.(2007) and Vinodhini and Narayanan (2009). The present work confirms the findings of Huges $(1976,1985)$, Olojo et al. (2005), and Osman et al.(2009) who have discussed the possible histopathological changes of gills due to heavy metals.

Mallat (1985) suggested that hyperplasia of squamous epithelial and chloride cells of gill serves as a physical and physiological defense mechanism against the toxicants. Alteration in the cellular components as a cause of depression in the respiratory activity of fishes exposed to acute metallic poisoning have been suggested by many workers (Gardner and Yevich, 1970; Gould and Karolus, 


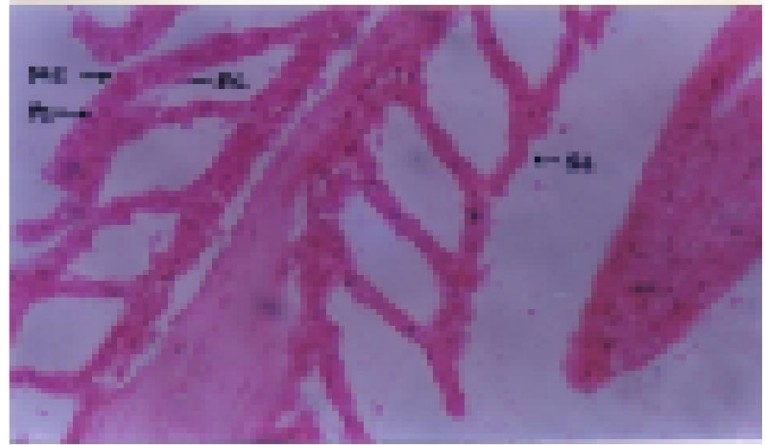

(1)

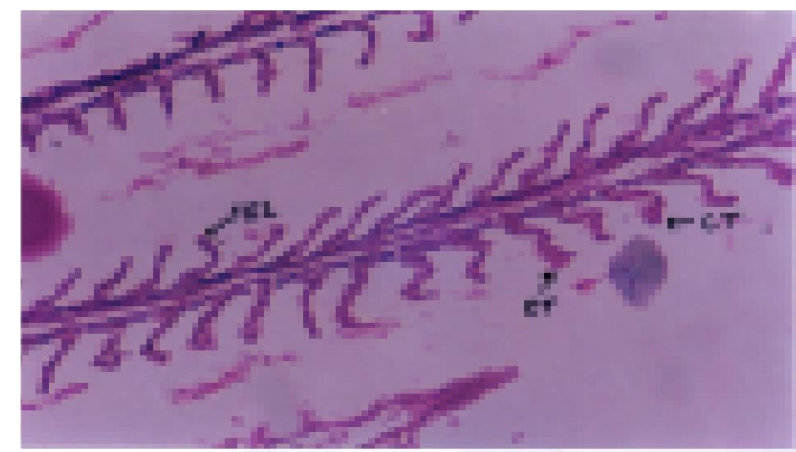

(2)

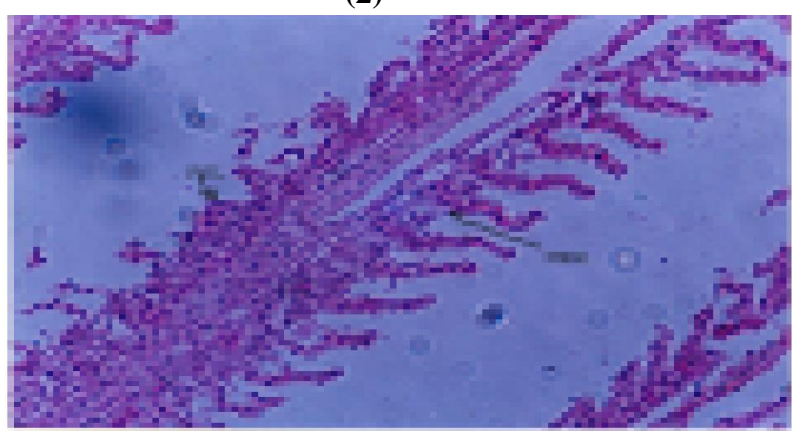

(3)

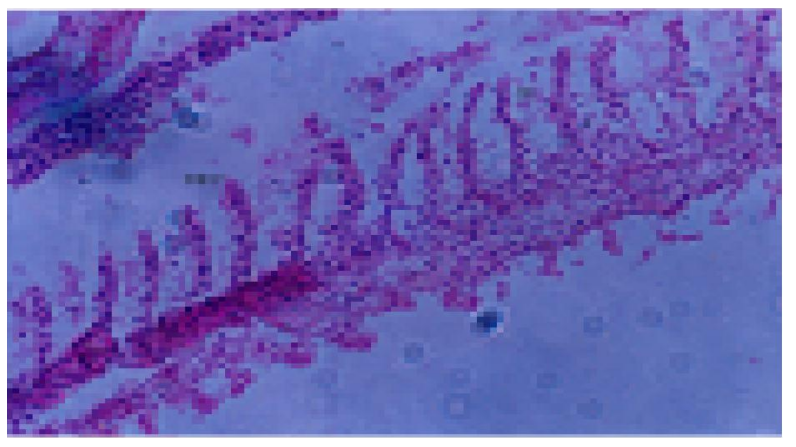

(4)

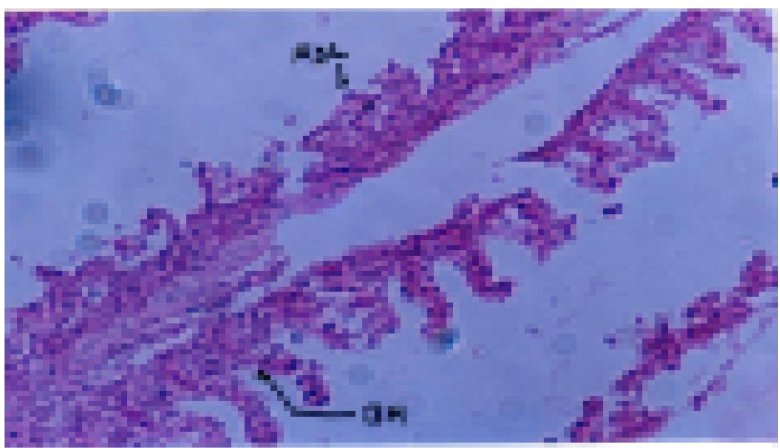

(5)

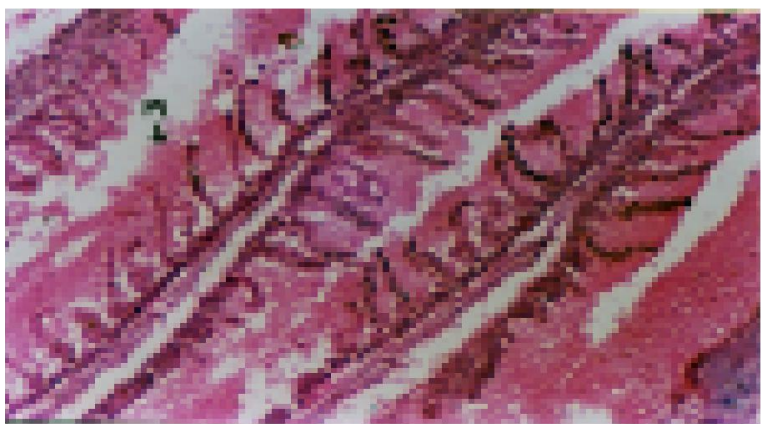

(6)

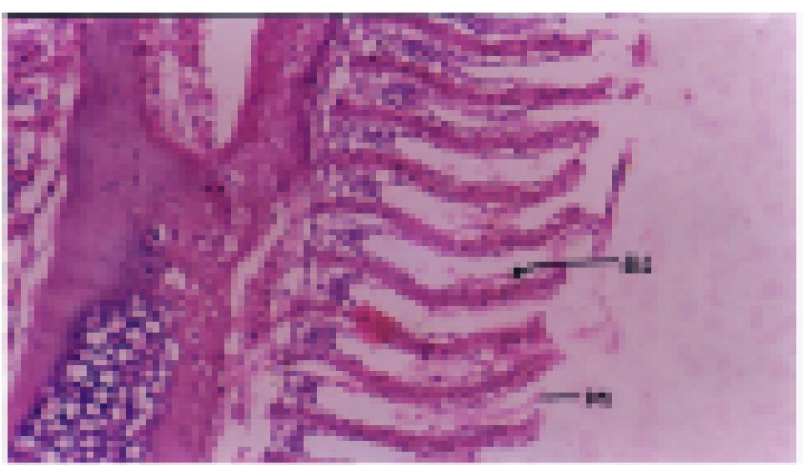

(7)

Figs. 1-7. T.S. of gills of the fish Labeo rohita illustrating 1) the normal structure showing secondary gill lamellae (SL) with epithelial lining (EL), mucus cells (MC) and pilaster cells (PC). 2) changes after exposure to chromium chloride for 10 days as evidenced by shrinkage of epithelial lining (SEL) and bending and thickening of the epithelial tissue at the pick of the lamellae, giving apperance of a club (CT), 3) changes after exposure to chromium chloride for 30 days as evidenced by fusion of secondary lamellae (FSL) and moderate basal hyperplasia (M BH), 4) changes after exposure to nickil chloride for 10 days as evidenvced by disr uption of epithelial cells (DEC) and secretion of mucus (M ), 5) changes after exposure to nickil chloride for 30 days as evidenvced by basal hyper plasia $(\mathrm{BH})$, fusion of two or more lamellae (FSL) and shortening of secondary lamellae, 6) changes after exposure to zinc chloride for 10 days as evdenced by excessive secreation of mucus between the secondary lamellae (M),7) changes after exposure to zinc chloride for 30 days as evuidenced by epithalial lifting (EL) and secreation of mucus only in the distal half (M). All preaparations in Ironhaemaloxylin-Eosin preaparation. X 400 . 
1974, Sastry and Sunitha, 1984 and Osman et al., 2009). Naidu et al. (1983) while studying the histology of gills of Sarotherodon mossambicus exposed to mercury, reported that the gills are vital respiratory and osmoregulatory organs and the cellular damage induced by the metal might impair the respiratory function of the fish by reducing the respiratory surface area. Srinivas and Rao (1999) investigated chromium induced alterations in the oxygen consumption of the fresh water fish, Labeo rohita and found that exposure of the fish Labeo rohita to $96 \mathrm{~h} \mathrm{LC}_{50}$ concentration of hexavalent chromium resulted into formation of club shaped secondary gill lamellae, fusion and necrosis of secondary gill lamellae and atrophy of central axis of the gill filament suggesting a decrease in the respiratory surface area. These results and the present observations are in agreement with several earlier observations (Srivastava et al., 1982; Kumar et al., 1988; Srivastava and Maurya, 1991; Christy, 1995; Olojo et al., 2005; Antonio et al.2007; Vinodhini and Narayanan 2009, Osman et al., 2009). As reported by Srivastava et al. (1982) and Osman et al. (2009) a long term exposure to mixture of heavy metals containing chromium and also in the present study resulted in the loss of respiratory epithelium showing erosion of epithelial cells with necrosis of respiratory epithelial layer moderate basal hyperplasia (Fig. 3) and visible signs of clubbing at the tips of secondary lamellae (Fig. 2). The findings thus, reveal that long term exposure to even a sublethal level of chromium, nickel and zinc caused a severe damage to respiratory organs like gills and in turn the respiratory function.

Particularly in zinc chloride exposed fishes, the epithelium from the basement membrane of the gill arch, filaments and the lamellae was found to be lifted up (Fig. 7), which is the most important sign of ecological degradation of surrounding water particularly due to toxicants. Such lifting of the epithelium (Fig. 7) from the gill tissue is related to the inflammatory conditions caused by the swelling of the lymphatics present between the vascular bed and the epithelium (Christie and Battle, 1963; Ansari and Srivastava, 1984; Roy et al., 1986; Antonio et al. 2007; and Osman et al., 2009). Edema with lifting of lamellar epithelium could be serve as a mechanism of defense because separation of epithelium of the lamellae increases the distance across which waterborne pollutants must diffuse to reach the blood stream (Arellano et al., 1999). The fusion of the gill lamellae is another effect seen in the fishes exposed to nickel chloride (Fig. 5) for thirty days. As the lamellar fusion reduces the respiratory area, the fish fails to extract adequate oxygen for its metabolic activities and thus asphyxiates (Ojha, 1993 and Olojo et al., 2005).

In the present investigation, secretion of mucus (Figs. 4, 6) was observed in all the three experimental groups leading to suffocation. Because of this, gaseous and ionic exchange might have become complicated and more energy might be needed to be spent on maintaining the basal metabolism of the animal reducing its capacity to perform work and survive in nature (Hughes, 1976 and Olojo et al., 2005).

\section{REFERENCES}

Abou EL-Naga, E. H., EL-Moselhy, K. M. and Hamed, M. A. (2005). Toxicity of cadmium and copper and their effect on some biochemical parameters of marine fish Mugil seheli. Egyptian. J . Aquat. Res., 31 (2), 60-71.

Adham, K.G, Hamed S.S., Ibrahim H.M. and Saleh R.A. (2002). Impaired functions in nile tilapia, or eochromis niloticus L, from polluted waters. Acta. Hydrochem. Hydrobiol., 28: 278-288.

Ansari, I.M. and Srivastava G.J. (1984). Histopathological changes in the gills of M ystus vitattus (Bloch) induced by sodium nitrate. J. Environ. Biol., 5 (2), 89-93.

Antonio,F-F, V. F-C. Jorge, G-S. Sofia, M.M. Sandra, C. Joao, M.Pedro and Antanio Fontainhas-Fernandes (2007). Histopathological changes in liver and gill epithelium of Nile tilapia, Oreochromis niloticus, exposed to waterborne copper. Pesq.Vet.Bras., 27(3): 103-109.

APHA (1998). American Public Health Association: Standard methods for examination of water and waste water. 20 th Ed: Lenore SC, Arnold EG and Andrew DE.

Arellano, J.M., Storch V. and Sarasquete, C. (1999). Histological changes and copper accumulation in liver and gills of Senegales sole, Solea senegalensis. E cotoxicol. Environ. Saf.,44: 6272.

Au, D.W.T. (2004). The application of histo-cytopathological biomarkera in marine pollution monitoring: Areview. M arine Pollut. Bull.,48: 817-834.

Bender, M. E. and Westman J. R. (1979). The toxicity of malathion and it's hydrolysis products to the eastern mud minnow, U mbra pygmea (Dekay). Chesapeake Science, 17:125-128.

Campbell, H.A., Handy, R.D. and Nimmo, M. (1979). Copper uptake kinetics across the gills of rainbow trout (Oncorhyncus mykiss) measured using an improved isolated perfused head technique. Aquat. Toxi col. , 46:177-190.

Chauhan, M.S. and Pandey A.K. (1987). Histopathological changes in the gills of Punctius ticto (Ham) following Khan river water exposure under ambient laboratory condition J.Environ.Biol., 8 (2): 121-127.

Chauhan, A. (1991). Effect of distillery effluent on liver Wain Ganga, Indian J. Env. H Ith, 33 (2): 203-207.

Christie, R.M. and Battle H.I., (1963). Histological effects of 3-trifluromethyl-4-nitrophenol (TFM) on larval lamprey and trout. Can. J . Zool., 41: 51-61.

Christy, I. (1995). Respiratory and histopathological responses of Catla catla,exposed to heavy metal,chromium J . Ecotoxicol. Envir on. M onit., 5 (4) : 263-268.

Farkas, A., Salanki, J. and Specziar, A. (2002). Relation between growth and heavy metal concentration in organs of bream,Abramis brama L. populating lake Balaton. Arch. Environ. Contam. Toxicol., 43: 236-243.

Filipovic, V. and Raspor, B.(2003). Metallothionein and metal 
levels in cytosol of liver, Kidney and brain in relation to growth parameters of Mullus surmuletus and Liza aurata. From the eastern Adriatic Sea. Water Res., 37 (13): 3253 3262.

Gardner, G.R. and Yevich R.P.I. (1970). Histological and haematological responses of an estuarine teleost to cadmium. J. Fish. Res. Bd. Can., 27: 2185-2196.

Gould, F. and Karolus, K.J.J. (1974). Physiological responses of cunner Tautogolobus adsper sus to cadmium. NOAA Tech. Rep. NM F S. SSRF 681, 21-25.

Hughes, G.M. (1976). Polluted fish respiratory physiology. In: Effects of pollutants on aquatic organism. (Edt Lockwood, A.P.M.), Cambridge University press, 160-183.

Hughes, G.M. (1985). Comparative studies of respiration as a guide to the selection of bio-indicators. Symp. Biomonitoring State Environ.,126-141.

Kock, G., Triendl, M. and Hofer, R. (1996). Seasonal patterns of metal accumulation in Arctic char (Salvelinus alpinus) from an oligotrophic Alpine lake related to temperature. Can. J. Fish. Aquat. Sci., 53:780-786.

Laurent, P. and Perry, S.F. (1991). Environmental effects on fish gill morphology. Physiol. Zool., 53:4-25.

Mallat, J. (1985). Fish gill structural changes induced by toxicants and other irritants: a statistical review. Can. J. Fish. Aquat. Sci., 42 : 630-648.

Naidu, A. K., Abhinender Naidu, K., and Ramamurthy, R. (1983). Acute effect of mercury toxicity on gill of teleost, Sarotherodon mossambicus. Ecotoxicol. Environ. Safty., 7: 455.

Nicolaidou, A. and Nott, J. (1989). Heavy metal pollution induced by ferronickel smelting plant in Greece. Sci. of the Total Environ., 84:113-117.

Nriagu, J.O. and Pacyna, J.M. (1988). Quantitative assessment of worldwide contamination of air, water and soils by trace metals. Nature, 333:134-139.

Ojha, J. (1993). Functional organization of teleostean gills. In: Advances in fish research, 1:71-98.

Olojo, E.A.A., Olurin, K.B., Mbaka G. and Oluwemimo A.D. (2005). Histopathology of gill and liver tissue of the african catfish Clarias gariepinus exposed to lead. African J. Biotechnol., 4(1): 117-122.
Osman, M. M., EL-Fiky, S. A., Soheir, Y.M. and Abeer, A. I. (2009). Impact of water pollution on histopathological and eletrophoretic characters of Auriochromis niloticus fish. Res. J. Environ. Toxicol.,3(1): 9-23.

Perry, S.F. and Laurent, P. (1993). Environmental effects on fish gill structure and function, p.231-264. In: Rankin J.C. and Jensen F.B. (ed.), Fish Ecophysiology. Chapman and Hall, London.

Ramesh kumar, B., Vijayalakshmi S. and Rajmanickam C., (1988). Toxicity effect of zinc sulfate on gill in the freshwater fish M ystus vittatus. Abst. No 67 National Symposium on Ecotoxicology, Annamalai Nagar.

Roy, K.J. and Dutta Munshi, J. S. (1991). Mallathion induced structural and maphometric changes of gills of a fresh water major carp Cirrhinus mrigala (Ham). J . Environ. Biol., 12: 79-87.

Roy, P.K., Datta Munshi, J.S. and Datta Munshi, J. (1986). Scanning electron microscopic evaluation of saponin on ills of the climbing perch, Anabas testudineus (Bloch), Ind.J . Expt. Biol., 24: 511-516.

Sastry, K.V. and Sunitha K.M. (1984). Chronic toxic effects of chromium in Channa punctatus. J. Environ. Biol., 5: 4-5.

Srinivas, V.S. and Rao, M.B. (1999). Chromium induced alterations in the oxygen consumption of the freshwater fish, Labeo rohita (Ham.). Poll. Res., 18 (4): 377-380.

Srivastava, V.M.S. and Maurya, R.S. (1991) Effect of chromium stress on gill and intestine of Mystus vittatus (Bloch): Scanning EM study. J. Ecobiol., 3 (1): 69-71.

Srivastava, V.M.S., Tripathi R.S. and Saxena A. K. (1982). Chromium induced histopathologic changes in some tissues of Punctius sophere (Ham). J. Biol. Res., 2: 67-68.

Vinodhini R. and Narayanan M.., (2009). Heavy metal induced histopathological alterations in selected organs of the $C$ prinus carpio L. (Common Carp). Int. J. Environ. Res., 3 (1):95100.

Weissnman, K. (1972). In: General zoological microtechniques, Blakiston company. Philadelphia.

Wilson, B.L., Schwarzer, R.R. and Etonyeaku N. (1986). The evaluation of heavy metals $(\mathrm{Cr}, \mathrm{Ni}$ and $\mathrm{Co})$ in the aqueous sediment surrounding a coal burning generating plant. J . Enviorn. Sci. Health, 21: 791-808. 